\title{
Formalization of Informal Settlements: A Study on Kabul Urban Areas
}

\author{
Ahmad Shoaib Jahani \\ Upgrading Directorate, Kabul Municipality, Kabul, Afghanistan \\ Email: shoaibjahani@gmail.com
}

How to cite this paper: Jahani, A. S. (2020). Formalization of Informal Settlements: A Study on Kabul Urban Areas. Current Urban Studies, 8, 446-455. https://doi.org/10.4236/cus.2020.83025

Received: March 30, 2020

Accepted: September 13, 2020

Published: September 16, 2020

Copyright $\odot 2020$ by author(s) and Scientific Research Publishing Inc. This work is licensed under the Creative Commons Attribution International License (CC BY 4.0).

http://creativecommons.org/licenses/by/4.0/

\begin{abstract}
Kabul Region with around 5 million population, which are $60 \%$ live in Kabul City 103,049 Ha (MUDH, 2016), covers around 69\% of Informal settlements, which suffer from lack of basic infrastructure, potable water, public spaces, and urban management system (Amiri \& Lukumwena, 2018). Urban Institutions and other related stakeholders try to cover the previous issues that happened due to mismanagement and rapid migration, after a long time public sectors supported preparing Master Plan in 2011 and other strategic plans to lead the city development toward a systematic manner (JICA, 2011a). Previous master plans and the relevant detailed plans did not apply very well and couldn't answer the Kabul Residents' demand, in addition after the year 2001 and rapid migration there was not a pre-plan to control the marginal part of the city. Then, the lack of acceptable method(s) among urban sectors and residents caused the issues to get hands together and change the City aspect. The purpose of this research is to find proper methods of intervention to formalize the informal settlements where the living standards get higher and the other side increasing the public services by tax collection. At the existing situation tax (Safaie) of $31 \%$ planned area is a budget of services provide by Kabul Municipality. This research will help Kabul Municipality and other stakeholder organizations to select the development tools for the betterment of urban conditions based on the existing situation, environmental and applicable according to the socio-economic situation of Kabul City with the lowest budget and demolition. Meanwhile, this will draw a proper path for those organizations implementing the improvements project without future development outlook for the city.
\end{abstract}

\section{Keywords}

Informal Settlements, Land Readjustment (LR), Urban Redevelopment (UR), Flat For Land (FFL), Upgrading 


\section{Introduction}

Kabul enlightens us with a wealth of cultural repositories through its architecture and urban form, which are the result of an evolving process of development through many generations (Sasaki, 2019).

A rapid migration toward Kabul city and demographical explosion with respect to considering the security and employment in surrounding provinces which gradually get worse than past years will face the city with a major challenge of informal settlements growth in suburban areas, agricultural land, vacant land, and hilly areas (MUDH, 2015). Figure 1 shows the rate of houses irregular and hillside in Kabul Urban areas. The interest growth rates of the population will directly cognition with informal settlements growth; this proportion of formal and informal settlements will be change from $69 \% / 31 \%$ to the benefit of informal settlements if the planners don't deliberate a proper countermeasure for this issue (JICA, 2011b).

Heretofore, the only applied method was the detailed plans which stopped due to lack of planners, implementation issues and being timed. A Zoning Procedure by Kabul Municipality had prepared to get the building permit for planned areas. Alongside, another zoning Procedure is work subject for unplanned areas. The only proposed methods like land readjustment and urban redevelopment which are introduced by JICA experts to Afghanistan, the implementation of such projects to formalize the informal settlements even are not adequate though will take a long time due to complex processes of implementation and land clarification (Author, 2020).

After civil war and Taliban Regime the urbanization trend through planning process stopped. Shelter demand, employment, education, facilities and other human welfares forced people to select Kabul as best option for settlement. Most of the agricultural areas converted to informal residential areas and hillsides grabbed and other governmental land grabbed by land mafias, this trend continues till now and creates several diverse urban issues. In the below figure the location of formal and informal settlements clearly identified (Author, 2020) (Figure 2).

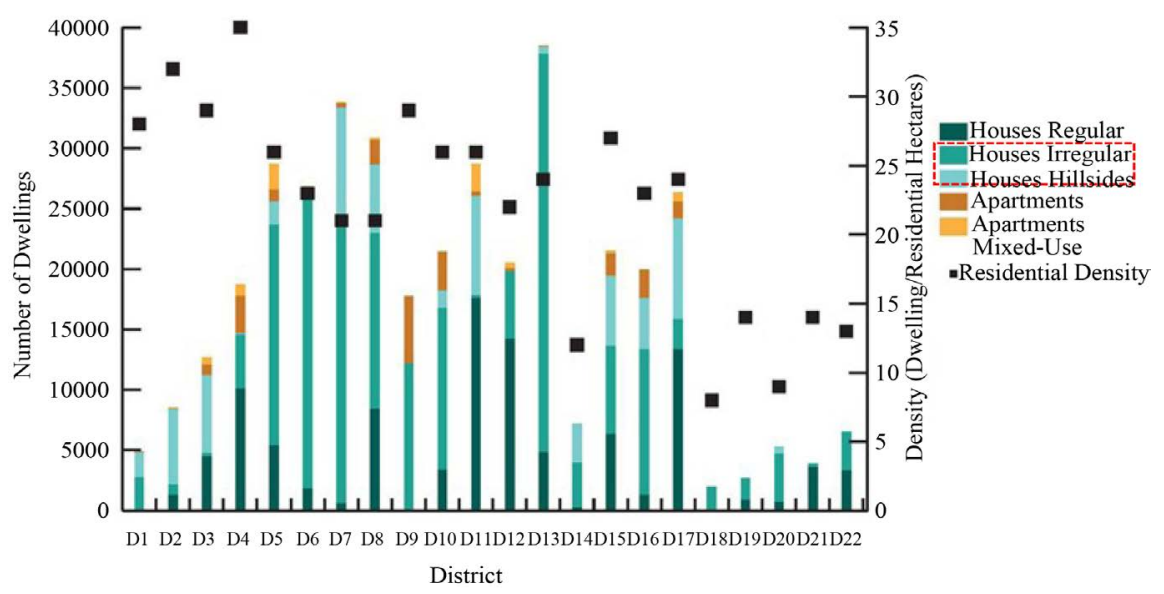

Figure 1. Number of dwellings. Source: State of Afghan Cities, Volume II (MUDH, 2015). 


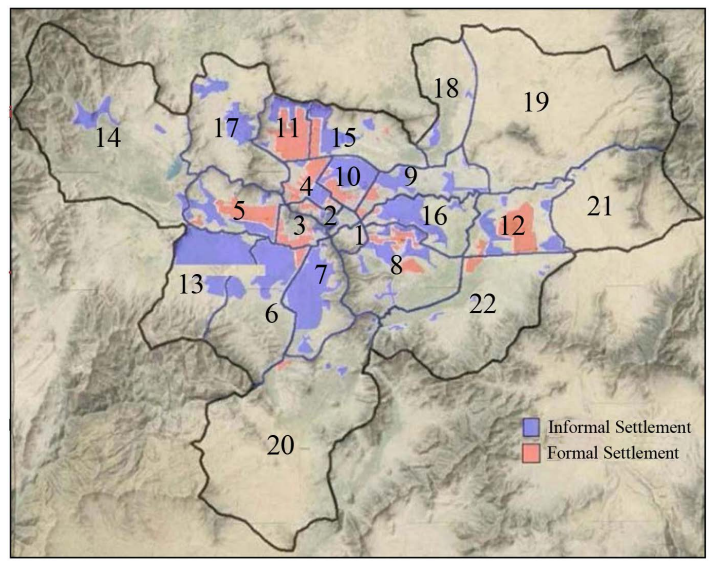

Figure 2. Formal and informal settlements by district. Source: CRIDA. Programs: Upgrading and Renovation of Unplanned Areas.

http://www.crida.gov.af/en/programs/upgrading-and-renovation-of-unplanne d-settlements

\subsection{Urban Redevelopment}

Urban Redevelopment (UR) is another successful method for the contexts of compact land developments. UR is unique concept that is directly connected with consolidation of small land plots into a large plot, with high/mid-rise-building and open spaces within the plot. Usually, it is used in larger urban projects and it consolidates the land plot area to flats according to the value and location of each land plot. It is more a vertical conversion of land plots to flats that contains not only the transfer of ownership but also covers the cost of building construction with provision and sale of financial flats (Kabul Municipality, 2017).

\subsection{Flat For Land (FFL)}

FFL is one type of Urban Redevelopment method that consist the vertical conversion of land plots to flats according to a determined percentage of conversion only. The conversion percentage is constant for all land plots in the project site area (Kabul Municipality, 2017).

\subsection{Land Readjustment}

Land Readjustment (LR) is a technique for managing the planned development of urban-fringe lands, whereby a government agency consolidates a selected group of land parcels and then designs, services and subdivides them into a layout of streets, open spaces and serviced building plots, with the sale of some of the plots for cost recovery and the distribution of the remaining plots back to the landowners to develop or to sell for development. LR is a horizontal conversion of land ownership only that contains the provision and sale of financial land for project's cost recovery (Kabul Municipality, 2017).

\subsection{Adaptable Land Readjustment}

In terminologies adaptation is "a form or structure modified to fit a changed en- 
vironment" (https://www.dictionary.com/browse/adaptation).

Therefore, adaptable land readjustment is a process of changes in original methods of Land Readjustment in which changes can be fit with socio-economic, Environmental and physical situation of the area (Author, 2020).

\subsection{Upgrading}

Upgrading is the method of situation betterment of unplanned areas from the perspectives of infrastructural, solving urban and environmental, enhancing of living quality and access to infrastructure with preservation of existing areas value (MUDH, 2017).

\section{Proposed Methods}

In this research, selection of proposed methods (Land Readjustment, Urban Redevelopment, Adaptable Land Readjustment and Upgrading) directly related to other factors such as existing condition of area, type of settlement and legal bases provided recently, specifically Regulation on Managing Affairs Related to Unofficial Urban Estates, 2018 and Land Readjustment and Urban Redevelopment Regulation (Kabul Municipality, 2020).

\subsection{Criteria for Selection of Development Method}

However here could be more criteria to select development methods, by the way, the most important criteria for selection of development methods which considered are in the below:

\subsubsection{Road Network and Accessibility}

Kabul road follow the radial form of the city, these roads play arterial role in the city where connected different parts of the city which consists of formal and informal settlements. Kabul road categorized in four types;

a) Primary Arterial Roads/Corridors ( $>40 \mathrm{~m}$ )

b) Secondary Roads/Spines (20 - $40 \mathrm{~m})$

c) Neighborhood Roads/Local Roads (10 - $20 \mathrm{~m})$

d) Residential Roads/Local Roads (<10 m) (Sasaki, 2019).

In the informal settlements residential roads/local roads mostly exist, proper access to transportation services and other facilities and amenities such as bus stops, bus station and parking don't exist in such areas, level of mortality due to firefighting's car access or small vehicles entrance to carry the emergency patients is higher than formal settlements (Sasaki, 2019).

\subsubsection{Plots Shapes}

Irregular form of plots which is not according to a preplanned that shows an organic settlements and a proper road network don't exist. Mechanism for project implementation is "Replotting". Replotting means the change of location, format and area of several plots of land to achieve a project's final scenario. (De Souza, Ochi, \& Hosono, 2018). 


\subsubsection{Public Facilities}

According to Land Readjustment and Urban Redevelopment Regulation definition for public facility is those buildings that construction expenses pay by responsible organization and include the educational, health, services, cultural, recreational and other public areas belong to Land Readjustment and Urban Redevelopment (Kabul Municipality, 2020).

\subsection{Type of Informal Settlements}

Kabul topography map shows that city is consisting of flat and hilly areas which are surrounded by mountains (Figure 3 ).

Different informal settlements growth in different land types, based on Kabul Urban Development Framework (KUDF) these settlements have divided into three types:

1) Informal Settlements in Flat Areas (0\% - 10\% slope);

2) Informal Settlements in Hilly Areas (10\% - 25\% slope);

3) Informal Settlements in Hazard Areas (More than 25\% slope) (Sasaki, 2019).

\subsection{Evaluation of Informal Settlements}

To formalize the informal settlements we need to know the periphery of each settlement from different perspective of planning such as process between related organizations, enacted laws and regulations, time needed, necessary budget allocation, land value and private investment in project. All these factors get hand together to select propose methods.

For each type of informal settlements below Tables 1-3 evaluate and offer proposes method(s).

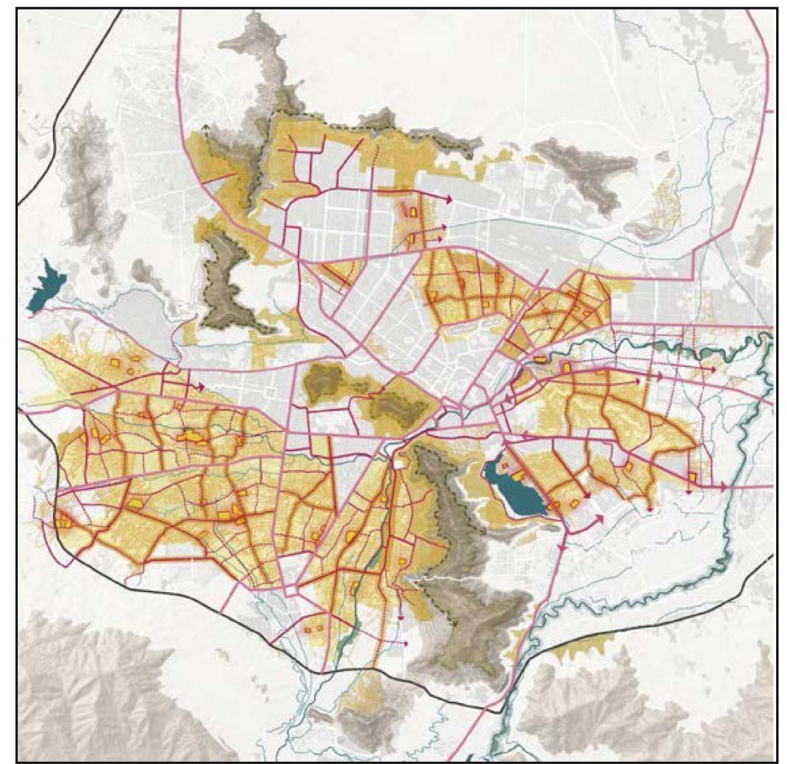

Figure 3. Integrating organic neighborhood. Source: Sasaki, 2019. 
Table 1. Informal settlements in flat areas. Source: Author, 2020.

\begin{tabular}{|c|c|c|c|c|}
\hline \multirow{2}{*}{ Type of Settlement } & \multirow{2}{*}{ How to Deal with } & \multicolumn{2}{|c|}{ Level of Formalization } & \multirow{2}{*}{$\begin{array}{l}\text { Propose } \\
\text { Methods }\end{array}$} \\
\hline & & Low Medium & High & \\
\hline \multicolumn{5}{|l|}{$\begin{array}{l}\text { Informal Settlements in } \\
\text { Semi Planned Areas }\end{array}$} \\
\hline $\begin{array}{l}\text { Planned Areas by KM } \\
\text { or MUDL (Areas have } \\
\text { approved plan by any) }\end{array}$ & $\begin{array}{l}\text { Plan modification and } \\
\text { acceptance by any } \\
\text { (KM or MUDL) }\end{array}$ & High & & Upgrading \\
\hline $\begin{array}{l}\text { Planned Areas by } \\
\text { Private Developers or } \\
\text { Grabbers without } \\
\text { any permission }\end{array}$ & $\begin{array}{l}\text { - Applying modification } \\
\text { and standards } \\
\text { - } \\
\text { - } \\
\text { Fines based on Related Laws. }\end{array}$ & High & & Upgrading \\
\hline $\begin{array}{l}\text { Grabbed Areas According } \\
\text { to Prepared Plan by } \\
\text { KM or Other entities }\end{array}$ & $\begin{array}{l}\text { Land Should Purchase by } \\
\text { Land owners according } \\
\text { to Law and Regulations }\end{array}$ & High & & Upgrading \\
\hline $\begin{array}{l}\text { Informal Settlements in } \\
\text { Unplanned Areas with } \\
\text { Irregular Shape }\end{array}$ & $\begin{array}{l}\text { Applying Arazi Regulation } \\
\text { for Land Purchasing }\end{array}$ & Low & & LR/FFL \\
\hline
\end{tabular}

Table 2. Informal settlements in hillside areas. Source: Author, 2020.

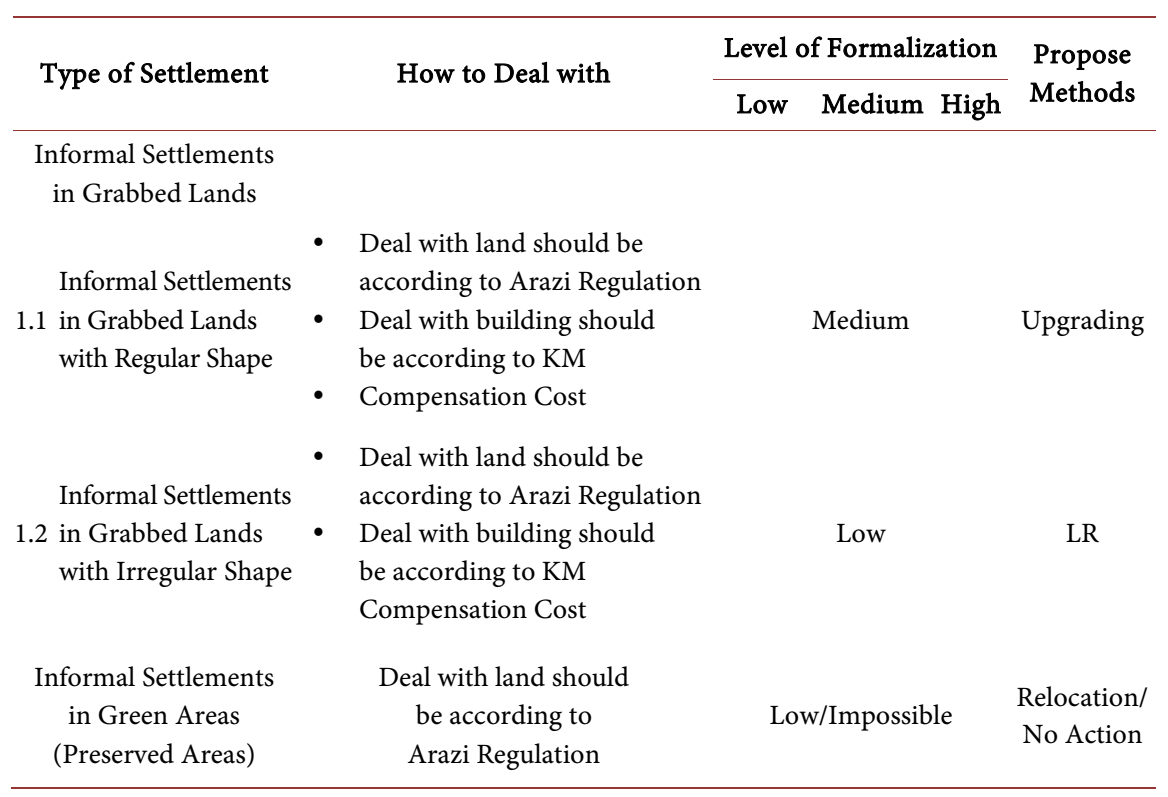

Table 3. Informal settlements in hazard areas. Source: Author, 2020.

\begin{tabular}{|c|c|c|c|c|c|}
\hline \multirow{2}{*}{ Type of Settlement } & \multirow{2}{*}{ How to Deal with } & \multicolumn{3}{|c|}{ Level of Formalization } & \multirow{2}{*}{ Propose Methods } \\
\hline & & Low & Medium & High & \\
\hline $\begin{array}{l}\text { Informal Settlements } \\
\text { in Hazard Areas } \\
\text { with Proper } \\
\text { Access to Road } \\
\text { and Facilities }\end{array}$ & $\begin{array}{l}\text { Exploring disaster } \\
\text { threats (In case of } \\
\text { High treat) } \\
\text { Deal with land } \\
\text { should be } \\
\text { according to } \\
\text { Arazi Regulation }\end{array}$ & & Low & & 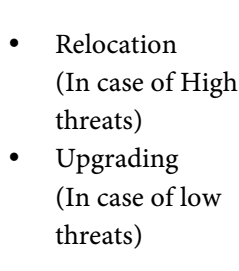 \\
\hline
\end{tabular}


Continued

\begin{tabular}{|c|c|c|c|}
\hline $\begin{array}{l}\text { Informal Settlements } \\
\text { in Hazard Areas } \\
\text { with Improper } \\
\text { Access to Road } \\
\text { and Facilities }\end{array}$ & $\begin{array}{l}\text { Exploring disaster } \\
\text { threats (In case of } \\
\text { High treat) } \\
\text { - Deal with land } \\
\text { should be } \\
\text { according to } \\
\text { Arazi Regulation }\end{array}$ & Low & 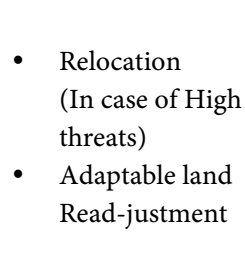 \\
\hline
\end{tabular}

\subsection{Level of Project According to Proposed Methods}

The proposed methods in this research prioritized based on the requiring budget allocation, time for project implementation and infrastructures (Chart 1).

\subsection{Development Process for Planning of Informal Settlements}

The proposed development process of planning for informal settlement is based on studies on social, environmental, economic and physical (Chart 2). After in detail study and evaluation the proposed method will identify to develop targeted informal settlements.

The proposed methods from start to implementation of project described in the below three process (Charts 3-5).

\section{Conclusion}

Different organizations participated in the development of informal settlements; unfortunately, most of the projects don't have sustainability due to discoordination among organizations. A continuous trend of project implementation without coordination to responsible organizations cause that a huge amount of governmental budget lost or wanders without any replication.

A proper mechanism for budget allocation in development projects will be the main aspect of this research; any development project will apply based on selected areas for Land Readjustment/Urban Redevelopment, Adaptable Land Readjustment and Upgrading.

Criteria for site selection of such projects came into Informal Settlements Manual; this will help us to identify parts of Kabul City as a planned area, keep the existing fabric and implement improvement projects in such areas, UN-HABITAT and MUDL should distribute the landownership Certificate based on this identifications. Meanwhile, areas select for Upgrading will take less time to be formalized.

This will result to include big parts of the city into the planned area, this will help the central government to collect tax (Safaie) and provide proper services to them.

\section{Research Limitations}

There may be some possible limitation in this research that affects the studies, therefore I have tried to do my best to tackle the issues and answer for several arisen questions. Lack of researches, policies and strategies about new methods 


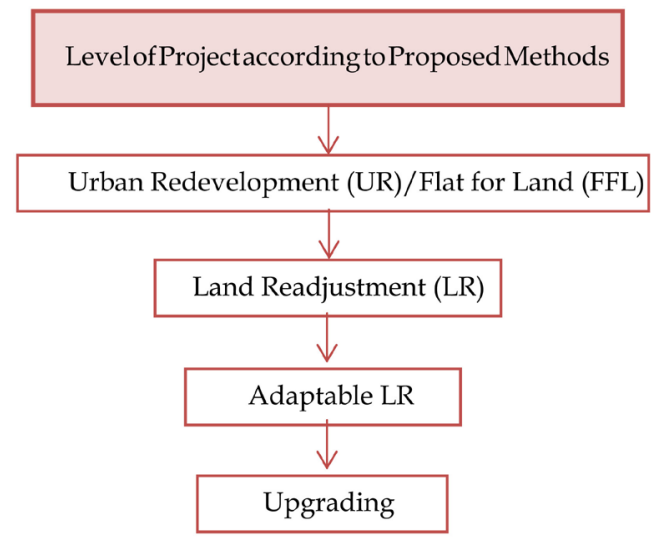

Chart 1. Level of project according to proposed methods. Source: Author.

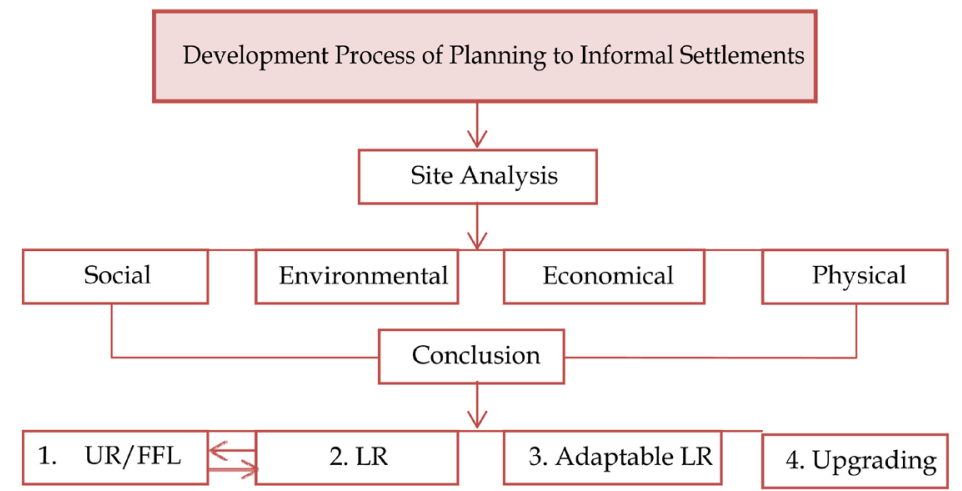

Chart 2. Development process of planning to informal settlements. Source: Author.

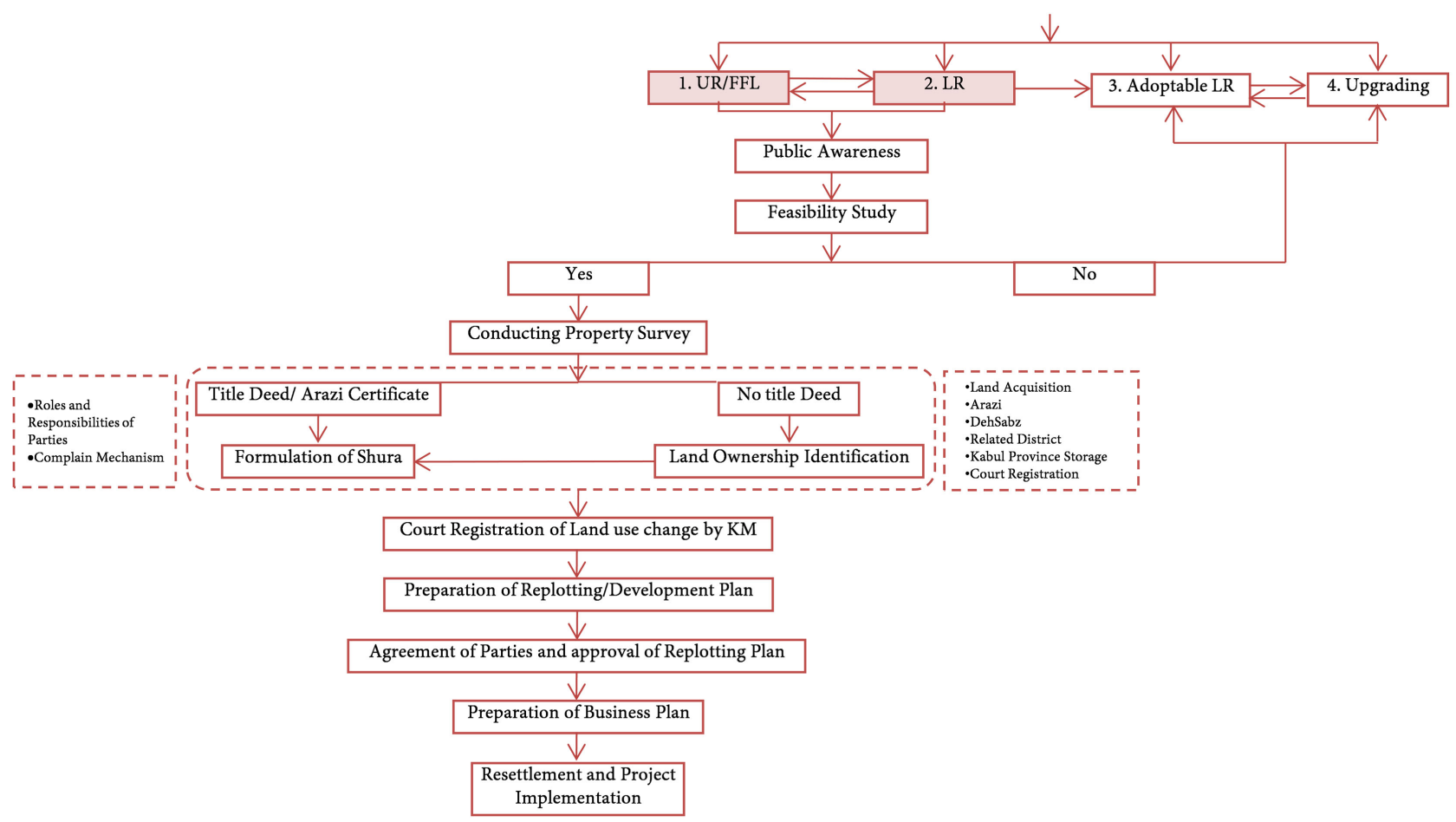

Chart 3. Formalization process through UR/FFL and LR projects. Source: Kabul Municipality, 2020. 


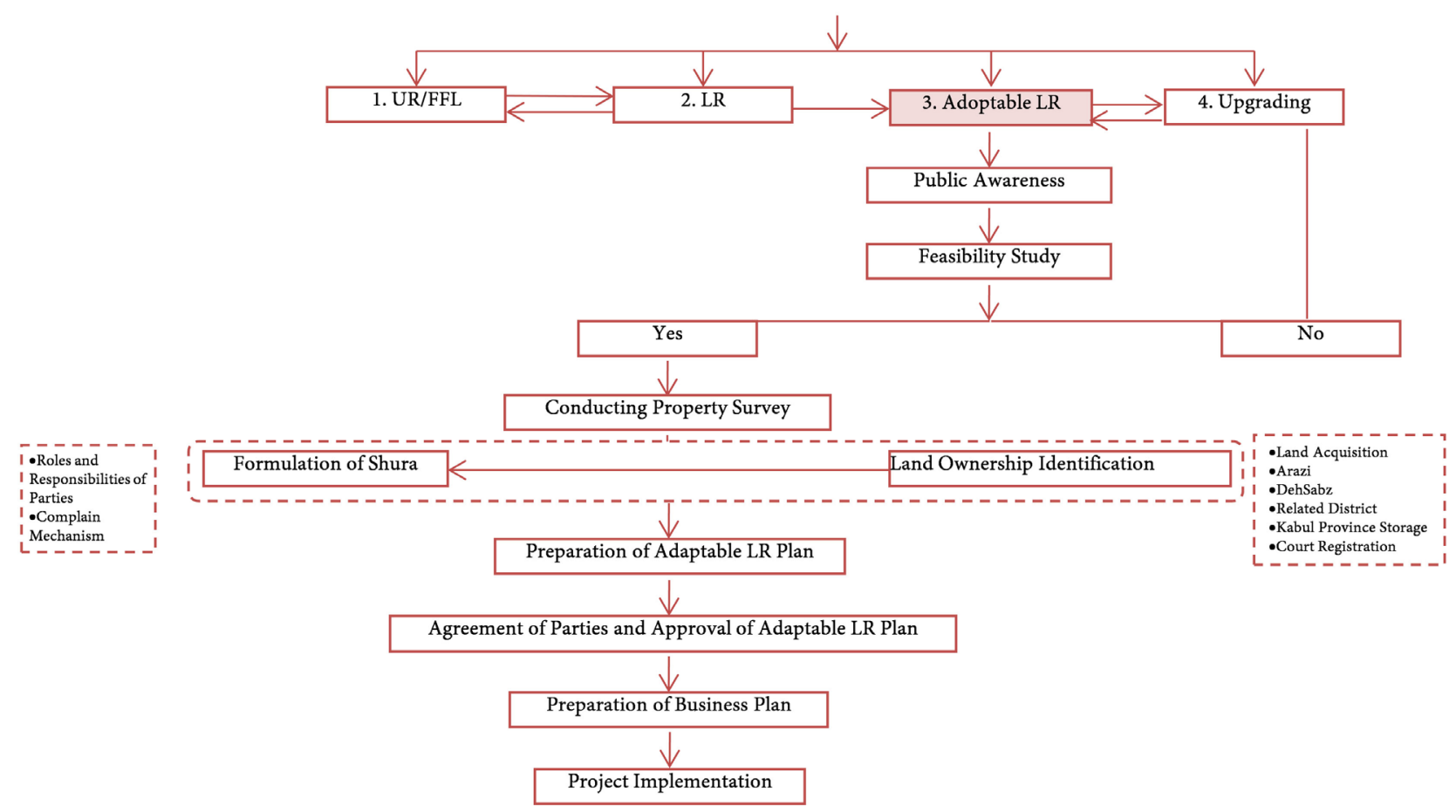

Chart 4. Formalization process through adaptable LR projects . Source: Author, 2020.

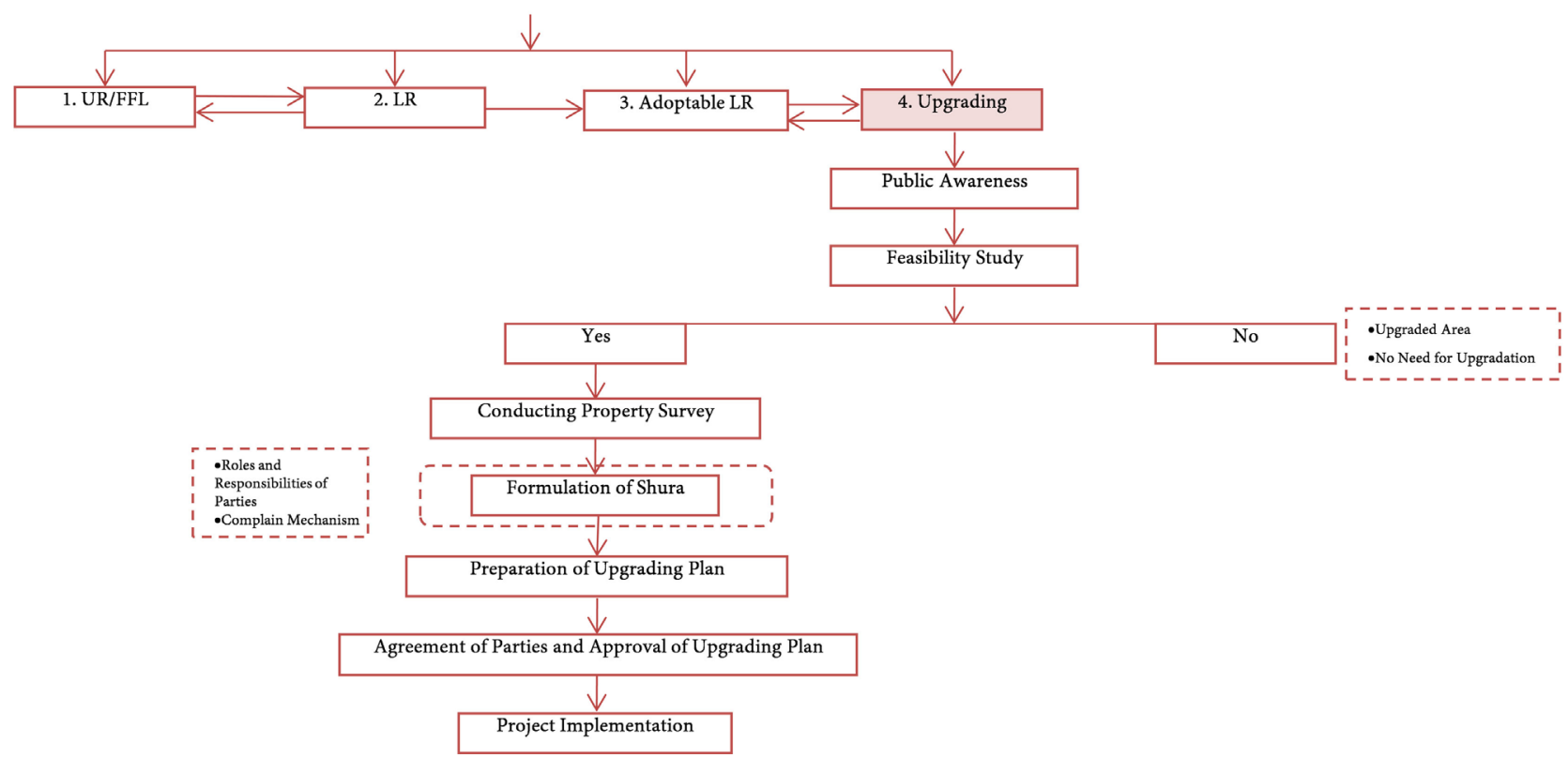

Chart 5. Formalization process through uprgrading projects. Source: Author, 2020.

of urban development in Afghanistan context with respect to consider that some laws, policies, regulations, procedures and manuals are under process or mentioned documents don't match due to not matching with urban situation of Afghanistan, such as socio-economic, political stability and other factors that need to be design and prepare with Afghanistan situation context caused that research should updated based on update of mentioned. 
Some data shall be collected from secondary sources, in case of unavailability of updated secondary sources, the outdate sources will select for design and intervention.

Meanwhile, some studies and findings behind this research are based on learnings and discussion with urban planners and designers of domestic and foreigners, these findings are based on experiences gained from developed countries, but, herein proposes are tried to be based on Afghanistan socio-economic situation.

For further research and studies researchers should consider all the publications and updated laws and policies about Land Readjustment, Urban Redevelopment and Upgrading. Although, methods that are applied in other countries do not match in other countries, thus, adaptable methods need to be designed and draw for the country.

\section{Acknowledgements}

This research is an output of experimental work beside my colleagues and Japanese experts; I would like to thank JICA team which helps us to prepare the manuals, procedures and regulations, these are all what I learned during trainings in Japan and India.

\section{Conflicts of Interest}

The author declares no conflicts of interest regarding the publication of this paper.

\section{References}

Amiri, B. A., \& Lukumwena, N. (2018). An Overview of Informal Settlement Upgrading Strategies in Kabul City and the Need for an Integrated Multi-Sector Upgrading Model. Current Urban Studies, 6, 348-365. https://doi.org/10.4236/cus.2018.63019

De Souza, F. F., Ochi, T., \& Hosono, A. (2018). Land Readjustment: Solving Urban Problems through Innovative Approaches. Japan International Cooperation Agency (JICA).

Japan International Cooperation Agency (JICA) (2011a). Report, Kabul City Master Plan.

Japan International Cooperation Agency (JICA) (2011b). Kabul City Current Status Report for Urban Development.

Kabul Municipality (2017). Land Readjustment and Urban Redevelopment Procedure.

Kabul Municipality (2020). Land Readjustment and Urban Redevelopment Regulation.

Ministry of Urban Development and Housing (MUDH) (2015). The State of Afghan Cities: Volume One. Kabul: MUDH.

Ministry of Urban Development and Housing (MUDH) (2016). Publication, Atlas of Afghan Cities.

Ministry of Urban Development and Housing (MUDH) (2017). Urban Development and Housing Law. Kabul: MUDH.

Sasaki (2019). Kabul Urban Design Framework (KUDF), Executive Summary, a Version of Sustainable and Vibrant Kabul, Sasaki Company, USA. 